\title{
PENGARUH PENCAMPURAN TEPUNG PISANG KEPOK, TEPUNG KACANG TUNGGAK dan TEPUNG DAUN KELOR TERHADAP KANDUNGAN MINERAL MP-ASI BISKUIT BAYI
}

\author{
Suburi Rahman ${ }^{*}$, Afe Dwiani1,
}

1Staf Pengajar Fakultas Pertanian Prodi Teknologi Hasil Pertanian, Universitas Nahdlatul Wathan Mataram email: suburi_rahman@yahoo.com

${ }^{*}$ Coresponding author.

\section{INFO ARTIKEL}

RiwayatArtikel:

Diterima: 12-02-2018

Disetujui: 22-02-2018

\section{Kata Kunci:}

Kalsium

Natrium

MP-ASI Biskuit bayi

\begin{abstract}
ABSTRAK
Abstrak: Penelitian ini bertujuan untuk mengetahui pengaruh penambahan tepung pisang, tepung kacang tunggak dan tepung daun kelor terhadap kandungan mineral kalsium (Ca) dan natrium (Na) pada MP-ASI biskuit bayi. MP-ASI biskuit bayi dibuat dengan 6 perlakuan yaitu PTK1-PTK6. Hasil analisa akan dibandingkan dengan SNI MP-ASI biskuit bayi (01-7111.22005). Dari hasil penelitian diketahui bahwa adanya perbedaan yang signifikan pada MP-ASI biskuit bayi (kandungan mineral kalsium dan natrium). Dari hasil analisa mineral diketahui bahwa untuk natrium dihasilkan biskuit yang memenuhi standar mutu SNI. Perlakuan PTK1 (100\% tepung pisang) menghasilkan kandungan natrium tertinggi yaitu 151,3 mg/100 g dan diikuti dengan PTK5 (Tepung pisang kepok 60\%, tepung daun kelor 15\%, tepung kacang tunggak 25\%). Untuk mineral kalsium tidak memenuhi standar SNI.
\end{abstract}

\begin{abstract}
This study aims to determine the effect of adding banana flour, cowpea flour and flour of moringa to calcium ( $\mathrm{Ca}$ ) and sodium (Na) mineral contents on MP-ASI baby biscuit. MP-ASI baby biscuits made with 6 treatments namely PTK1-PTK6. The results of the analysis will be compared with Indonesian National Standard (SNI) MP-ASI baby biscuit (01-7111.2-2005). From the results of the research note that there are significant differences in the baby's biscuit ASI-biscuits (calcium and sodium mineral content). From the results of mineral analysis, it is known that for sodium biscuits are produced that meet SNI quality standards. The PTK1 (100\% banana flour) treatment resulted in the highest sodium content of $151.3 \mathrm{mg} / 100 \mathrm{~g}$ and followed by PTK5 (60\% pure banana flour, 15\% moringa flour, 25\% cow flour). For calcium minerals do not meet SNI standards.
\end{abstract}

\section{A. LATAR BELAKANG}

Mineral dapat diklasifikasikan menurut jumlah yang dibutuhkan tubuh. Mineral utama (mayor) adalah mineral yang kita perlukan lebih dari $100 \mathrm{mg}$ sehari, sedangkan mineral minor (trace elements) adalah yang kita perlukan kurang dari $100 \mathrm{mg}$ sehari. Kalsium, tembaga, fosfor, kalium, natrium dan klorida adalah contoh mineral utama, sedangkan kromium, magnesium, yodium, besi, flor, mangan, selenium dan zinc adalah contoh mineral minor [2]. Mineral tersebut banyak terdapat dalam bahan pangan dan beberapa diantaranya adalah adalah kalsium (Ca), Seng ( $\mathrm{Zn})$, besi ( $\mathrm{Fe}$ ) dan natrium (Na).

Kalsium (Ca) merupakan mineral yang dikandung oleh tubuh manusia sekitar 22 gram kalsium per $\mathrm{kg}$ berat badan tanpa lemak. Sebanyak 99\% kalsium terdapat dalam tulang dan gigi. Karena bayak terdapat pada tulang dan gigi maka kalsium berfungsi membentuk tulang dan gigi manusia. Kalsium sering difortifikasi atau ditambahkan dalam bahan pangan [4]. Natrium/sodium merupakan kation utama dari cairan ekstraseluler, pengontrolan osmolaritas dan volume cairan tubuh. Fungsi dari natrium adalah dalam plasma darah dan cairan berperan dalam menyelimuti jaringan, berperan dalam menghasikan tekanan osmotik yang mengatur pertukaran cairan antara sel dan cairan disekitarnya, menentukan volume dalam cairan ekstra seluler dan untuk mempertahankan keseimbangan tubuh [5].

Faktor yang mempengaruhi terjadinya gangguan tumbuh kembang bayi 6-24 bulan di Indonesia berdasarkan hasil survei Departemen Kesehatan adalah rendahnya mutu MP-ASI dan ketidak sesuaian pola asuh yang diberikan sehingga kecukupan energi dan beberapa zat gizi mikro seperti kalsium, dan zink tidak terpenuhi. Usia 6-24 bulan rawan terjadi kurang gizi karena adanya peningkatan kebutuhan 24$30 \%$. Oleh karena itu, pada periode ini anak mulai diperkenalkan dengan makanan pendamping air susu ibu (MP-ASI). Penyediaan MP-ASI dengan kepadatan mikronutrien dan frekuensi pemberian yang tepat harus diperhatikan sejak anak berusia 6 bulan untuk mencegah terjadinya stunting [7]

Berdasarkan hasil Riset Kesehatan Dasar (Riskesdas) 2010 prevalensi balita stunting untuk skala nasional sebesar 35,6 \%, walaupun turun 1,2\% dibandingkan tahun 2007 (36,8 \%) tetapi belum mencapai target perbaikan gizi. Rencana Pembangunan Jangka Menegah Nasional(RPJMN) tahun 2015 sebesar $20 \%$. Angka kejadian stunting jika dilihat berdasarkan 
kelompok umur, prevalen sistunting pada balita 6-11 bulan $32,1 \%$ dan meningkat menjadi $41,5 \%$ pada usia 12-23 bulan [8].

Upaya perbaikan gizi masyarakat dapat dilakukan dengan peningkatan konsumsi pangan melalui pendekatan penganekaragaman pangan. MP-ASI biskuit bayi biasanya terbuat dari tepung terigu atau tepung beras. Hal ini kurang mendukung penganekaragaman pangan. Gandum sebagai bahan baku terigu merupakan komoditas impor yang hampir tidak diproduksi di Indonesia. Substitusi terigu dengan tepung komposit bertujuan untuk meningkatkan kandungan zat gizi dan memperbaiki sifat fisik bahan. MP-ASI banyak dipasarkan dalam bentuk bubur dan biskuit. Bentuk biskuit dapat melatih bayi untuk belajar manggenggam dan menggigit serta mempunyai daya rehidrasi sehingga dapat diencerkan menjadi bubur bayi [3].

Pisang dan daun kelor merupakan beberapa bahan pangan lokal yang mengandung mineral baik natrium maupun kalsium. Tepung pisang mengandung kalsium sebesar 30-39 mg [4] dan daun kelor kering mengandung kalsium sebesar $1897 \mathrm{mg} / 100 \mathrm{~g}$ serta natrium sebesar 220 $\mathrm{mg} / 100 \mathrm{~g}$ [10]. Pencampuran antara beberapa jenis tepung tersebut diharapkan dapat dapat meningkatkan kandungan kalsium (Ca), natrium (Na), Seng (Zn) dan Besi (Fe) dalam MP-ASI biskuit bayi sehingga kebutuhan bayi dan balita akan mineral tersebut dapat terpenuhi.

Berdasarkan latar belakang tersebut maka dilakukan penelitian mengenai pengaruh pencampuran tepung pisang kepok, tepung kacang tunggak dan tepung daun kelor terhadap kandungan mineral mp-asi biskuit bayi

\section{B. METODE PENELITIAN}

\section{Bahan dan Alat}

Bahan yang digunakan dalam penelitian ini adalah tepung pisang kepok, tepung kacang tunggak, tepung daun kelor, gula, margarin, susu bubuk dan telur. Peralatan yang digunakan adalah glassware, timbangan kasar, timbangan analitik, cetakan kue, kompor gas, mixer, oven, sendok, garpu, mangkok, loyang, yiru, pisau stainless steel, ayakan 80 mesh, eksikator, labu ukur, pipet, tampah, wajan stainless steel, baskom plastik, mangkok plastik, lap, piring, panelis, kuisioner dan alat tulis menulis

\section{Pembuatan tepung pisang}

Pisang yang digunakan adalah pisang dengan tingkat kematangan $3 / 4$ matang. Pisang disortasi, dikupas, dan direndam dalam air garam (1\%), kemudian diiris tipis dan dikeringkan menggunakan pengering kabinet. Chips pisang yang telah kering kemudian digiling, diayak, kemudian dikemas dengan kemasan plastik dan diletakkan dalam toples kedap udara.

\section{Pembuatan tepung kacang tunggak}

Kacang tunggak yang digunakan berwarna coklat. Sortasi pada kacang tunggak dilakukan dua kali, sortasi awal menggunakan tampah, sedangkan sortasi kedua menggunakan cara basah yaitu dengan merendam kacang tunggak dengan air, kacang tunggak yang berkualitas kurang baik akan mengapung dan disingkirkan. Kacang tunggak yang telah disortasi kemudian disangrai hingga tercium bau harum. Kacang tunggak yang telah disangrai kemudian didinginkan kemudian digiling dan diayak, dikemas dengan kemasan plastik dan diletakkan dalam toples kedap udara.

\section{Pembuatan tepung daun kelor}

Daun kelor yang digunakan adalah daun yang berwarna hijau tua mengkilat. Daun dipetik dan disortasi dari batangnya. Daun dicuci kemudian dikeringkan menggunakan sinar matahari Daun kelor yang telah kering kemudian dihancurkan dengan menggunakan blender dan diayak kemudian dikemas dengan kemasan plastik dan diletakkan dalam toples kedap udara.

\section{Pembuatan MP-ASI biskuit bayi}

Bahan baku seperti tepung pisang kepok, tepung kacang tunggak dan tepung daun kelor beserta bahan tambahan seperti margarin, gula halus, susu, dan telur. Kocok margarin dan gula dengan mikser hingga adonan licin. Masukkan telur dan mikser hingga rata. Setelah adonan tercampur rata kemudian mikser dimatikan. Setelah itu masukkan tepung dan susu bubuk kemudian aduk menggunakan sendok plastik hingga adonan kering, licin dan elastis. Biskuit dicetak menggunakan sendok es krim dan diletakkan pada loyang yang sebelumnya telah dioles margarin. Pipihkan adonan menggunakan sendok. MP-ASI biskuit bayi kemudian dipanggang hingga matang.

\section{Uji Mineral}

Kandungan mineral pada MP-ASI biskuit bayi dilakukan dengan menggunakan alat Automic Absorbtion Spectrophotometer (AAS) Flame.

\section{Analisa statistik}

Penelitian ini menggunaan Rancangan Acak Lengkap (RAL) dengan 6 perlakuan dan 3 ulangan. Data yang dihasilkan dianalisa menggunakan analisa keragaman (ANOVA) menggunakan Microsoft Excel dan Program CoSTAT. Jika terdapat beda nyata antara perlakuan, maka akan dianalisa lebih lanjut menggunakan BNT (Beda Nyata Terkecil) dengan taraf 5\%. Hasil rancangan dalam penelitian ini disajikan pada Tabel 1 dibawah ini:

\begin{tabular}{|l|c|c|c|}
\hline Perlakuan & $\begin{array}{c}\text { Tepung } \\
\text { Pisang (\%) }\end{array}$ & $\begin{array}{c}\text { Tepung } \\
\text { Kacang } \\
\text { Tunggak(\%) }\end{array}$ & $\begin{array}{c}\text { Tepung } \\
\text { Kelor (\%) }\end{array}$ \\
\hline PTK1 & 100 & - & - \\
\hline PTK2 & 90 & 10 & - \\
\hline PTK3 & 80 & 15 & 5 \\
\hline PTK4 & 70 & 20 & 10 \\
\hline PTK5 & 60 & 25 & 15 \\
\hline PTK6 & 50 & 30 & 20 \\
\hline
\end{tabular}




\section{HASIL DAN PEMBAHASAN}

Tabel 2. Hasil analisa ragam kandungan mineral MP-ASI Biskuit bayi dari campuran Tepung Pisang, Tepung Kacang Tunggak dan Tepung Kelor

\begin{tabular}{cc}
\hline Parameter & Hasil \\
\hline Mineral Ca (mg/100 g) & $\mathrm{S}$ \\
Mineral Na (mg/100 g) & $\mathrm{S}$ \\
Mineral Zn (mg/100 g) & $\mathrm{S}$
\end{tabular}

Keterangan : S = Signifikan (berbeda nyata); NS = Non Signifikan (tidak berbeda nyata)

\section{Mineral Ca}

Ca atau kalsium dibutuhkan manusia lebih banyak dari mineral lainnya sekitar 1,5-2\%. Kalsium berfungsi dalam pembentukan tulang, membantu otot berkontraksi, jantung berdetak, sistem saraf memberikan rangsangan dan mengatur pembekuan darah jika terjadi luka [1]. Sumber utama kalsium pada bahan pangan adalah susu, sayuran berwarna hijau, buah pisang, kacang-kacangan dan biji-bijian serta tulang ikan terutama ikan teri [2].

Rerata kadar Ca pada MP-ASI biskuit bayi untuk perlakuan PTK1-PTK6 dalam penelitian ini bervariasi, antara $2,59-18,88 \mathrm{mg} / 100$ g. Kadar Ca paling rendah adalah pada perlakuan PTK2 $(2,59$ $\mathrm{mg} / 100 \mathrm{~g}$ ) dan yang tertinggi adalah pada perlakuan PTK6 (18,88 mg/100 g). Hasil analisa ragam (Tabel 2) menunjukkan bahwa perlakuan formulasi pada MP-ASI biskuit bayi berpengaruh nyata $(\mathrm{p}<0,05)$ terhadap kadar Ca MP-ASI biskuit bayi yang dihasilkan. Hasil analisa kadar Ca MP-ASI biskuit bayi disajikan pada Gambar 1.

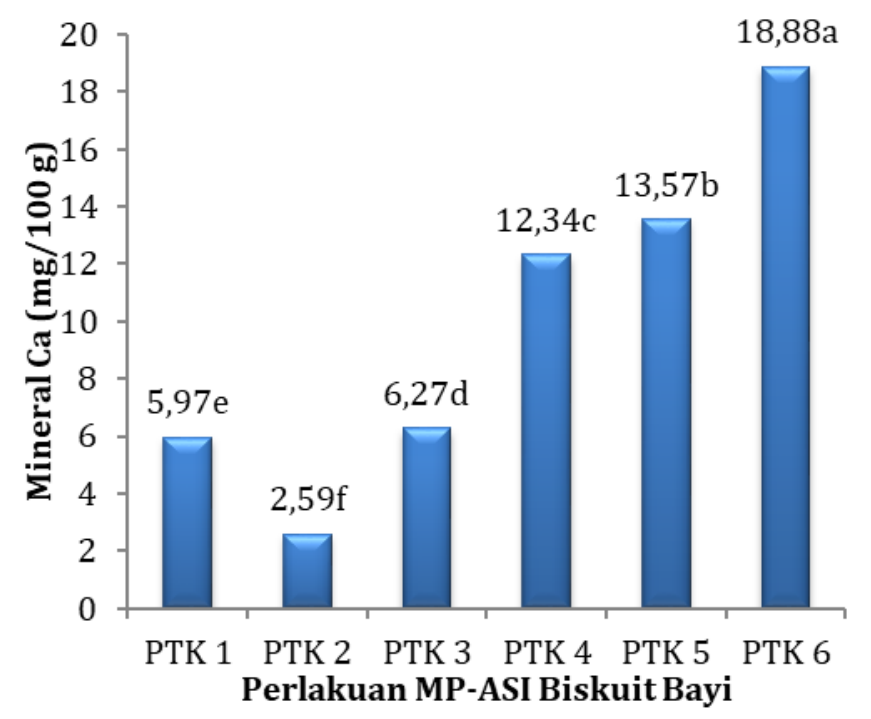

Gambar 1. Hasil analisa mineral Ca (mg/100 g) pada MPASI biskuit bayi
Keterangan: Angka rerata yang diikuti dengan huruf yang sama tidak berbeda nyata pada uji BNT 5\%

*)Perlakuan:

PTK1 = Tepung pisang kepok 100\%

PTK2 = Tepung pisang kepok 90\%: tepung daun kelor $0 \%$ : tepung kacang tunggak $10 \%$

PTK3 =Tepung pisang kepok $80 \%$ : tepung daun kelor 5\%: tepung kacang tunggak $15 \%$

PTK4 = Tepung pisang kepok 70\%: tepung daun kelor $10 \%$ : tepung kacang tunggak $20 \%$

PTK5 = Tepung pisang kepok 60\%: tepung daun kelor 15\%: tepung kacang tunggak $25 \%$

PTK6 = Tepung pisang kepok 50\%: tepung daun kelor 20\%: tepung kacang tunggak $30 \%$

Dari Gambar 1 dapat dilihat bahwa perlakuan PTK1 berbeda nyata dengan semua perlakuan, begitu pula dengan perlakuan PTK2 hingga PTK6 berbeda nyata dengan semua perlakuan. Pada Gambar 1 dapat dilihat bahwa pada perlakuan PTK2 hingga perlakuan PTK6 dihasilkan kadar Ca yang semakin tinggi sedangkan pada perlakuan PTK1 dihasilkan kadar Ca lebih tinggi dibandingkan perlakuan PTK2 pada MP-ASI biskuit bayi. Pada Gambar 18, semakin tinggi penambahan tepung kacang tunggak dan tepung daun kelor serta semakin rendah penambahan tepung pisang kapok maka semakin meningkat kadar Ca yang dihasilkan. Akan tetapi kandungan kalsium (Ca) pada MP-ASI ini tidak memunuhi persyaratan mutu SNI. Hal ini mungkin diakibatkan oleh berkurangnya kadar kalsium pada bahan baku karena proses pengolahan.

Menurut SNI 01-7111.2-2005 tentang MP-ASI biskuit bayi menyebutkan bahwa syarat mutu untuk mineral Ca sebesar $200 \mathrm{mg} / 100 \mathrm{~g}$. Hasil analisa menunjukkan bahwa kandungan Ca tertinggi sebesar $18,84 \mathrm{mg} / 100 \mathrm{~g}$ sehingga semua perlakuan pada pembuatan biskuit MP-ASI dari campuran tepung pisang, tepung kacang tunggak dan tepung kelor belum memenuhi syarat SNI.

\section{Mineral Na}

$\mathrm{Na}$ atau sodium sebagian besar dikonsumsi oleh manusia dan ditambahkan pada bahan pangan dalam bentuk sodium klorida ( $\mathrm{NaCl}$ ). Konsumsi sodium yang tinggi dapat meningkatkan tekanan darah dan tidak baik bagi kesehatan. Bahan pangan sumber utama sodium adalah daging, ikan laut, kerang, telur dan keju [3].

Rerata kadar Na pada MP-ASI biskuit bayi untuk perlakuan PTK1-PTK6 dalam penelitian ini bervariasi, antara 140,9 - 151,3 mg/ 100 g. Kadar Na paling rendah adalah pada perlakuan PTK2 $(140,9$ $\mathrm{mg} / 100 \mathrm{~g}$ ) dan yang tertinggi adalah pada perlakuan PTK6 (151,3 mg/100 g). Hasil analisa ragam (Tabel 2) menunjukkan bahwa perlakuan formulasi pada MP-ASI 
biskuit bayi berpengaruh nyata $(\mathrm{p}<0,05)$ terhadap kadar Na MP-ASI biskuit bayi yang dihasilkan. Hasil analisa kadar Na MP-ASI biskuit bayi disajikan pada Gambar 2.

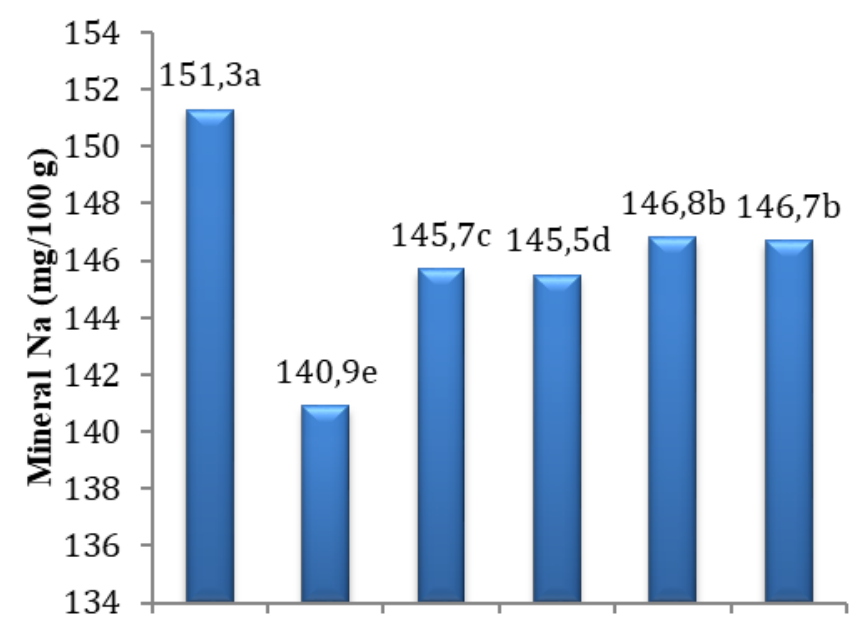

PTK 1 PTK 2 PTK 3 PTK 4 PTK 5 PTK 6 Perlakuan MP-ASI Biskuit Bayi

Gambar 2. Hasil analisa mineral Na (mg/100 g) pada MPASI biskuit bayi

Keterangan: Angka rerata yang diikuti dengan huruf yang sama *)Perlakuan: tidak berbeda nyata pada uji BNT 5\%

PTK1 = Tepung pisang kepok $100 \%$

PTK2 = Tepung pisang kepok 90\%: tepung daun kelor 0\% : tepung kacang tunggak $10 \%$

PTK3 =Tepung pisang kepok $80 \%$ : tepung daun kelor 5\%: tepung kacang tunggak $15 \%$

PTK4 = Tepung pisang kepok 70\%: tepung daun kelor 10\%: tepung kacang tunggak $20 \%$

PTK5 = Tepung pisang kepok 60\%: tepung daun kelor 15\%: tepung kacang tunggak $25 \%$

PTK6 = Tepung pisang kepok 50\%: tepung daun kelor 20\%: tepung kacang tunggak 30\%

Dari Gambar 2 dapat dilihat bahwa perlakuan PTK1 berbeda nyata dengan semua perlakuan, begitu pula dengan perlakuan PTK2 hingga PTK4 berbeda nyata dengan semua perlakuan. Untuk perlakuan PTK5 dan PTK6 berbeda nyata dengan perlakuan PTK1PTK4, tetapi tidak berbeda nyata antar perlakuan. Pada Gambar 2 dapat dilihat bahwa pada perlakuan PTK2 perlakuan PTK3, kadar $\mathrm{Na}$ meningkat, tetapi pada perlakuan PTK4 kadar $\mathrm{Na}$ menurun dan perlakuan PTK5 dan PTK6, kadar Na semakin meningkat.

Menurut SNI 01-7111.2-2005 tentang MP-ASI biskuit bayi menyebutkan bahwa syarat mutu untuk mineral $\mathrm{Na}$ sebesar $100 \mathrm{mg} / 100 \mathrm{~g}$. Hasil analisa menunjukkan bahwa kandungan mineral $\mathrm{Na}$ yang dihasilkan dari semua perlakuan telah memenuhi standar SNI. Nilai mineral Na yang paling rendah dihasilkan oleh PTK2 (140,9 mg/100 g), dan nilai mineral Na yang tertinggi dihasilkan oleh PTK1 (151,3 $\mathrm{mg} / 100 \mathrm{~g}$ ).

\section{Mineral $\mathrm{Zn}$}

Zn atau seng merupakan mineral makro terpenting kedua untuk manusia. Seng didapat dari makanan maupun sudah disediakan oleh enzim pencernaan. Seng memiliki berbagai fungsi yaitu berperan dalam pembentukan kulit, metabolisme jaringan ikat dan penyembuh luka (Cakrawati dan Mustika, 2014).

Rerata kadar Zn pada MP-ASI biskuit bayi untuk perlakuan PTK1-PTK6 dalam penelitian ini bervariasi, antara 2,29 - 4,97 mg/100 g. Kadar Zn paling rendah adalah pada perlakuan PTK1 $(2,29$ $\mathrm{mg} / 100 \mathrm{~g}$ ) dan yang tertinggi adalah pada perlakuan PTK6 (4,97 mg/100 g). Hasil analisa ragam (Tabel 2) menunjukkan bahwa perlakuan formulasi pada MP-ASI biskuit bayi berpengaruh nyata $(p<0,05)$ terhadap kadar Zn MP-ASI biskuit bayi yang dihasilkan. Hasil analisa kadar Zn MP-ASI biskuit bayi disajikan pada Gambar 3.

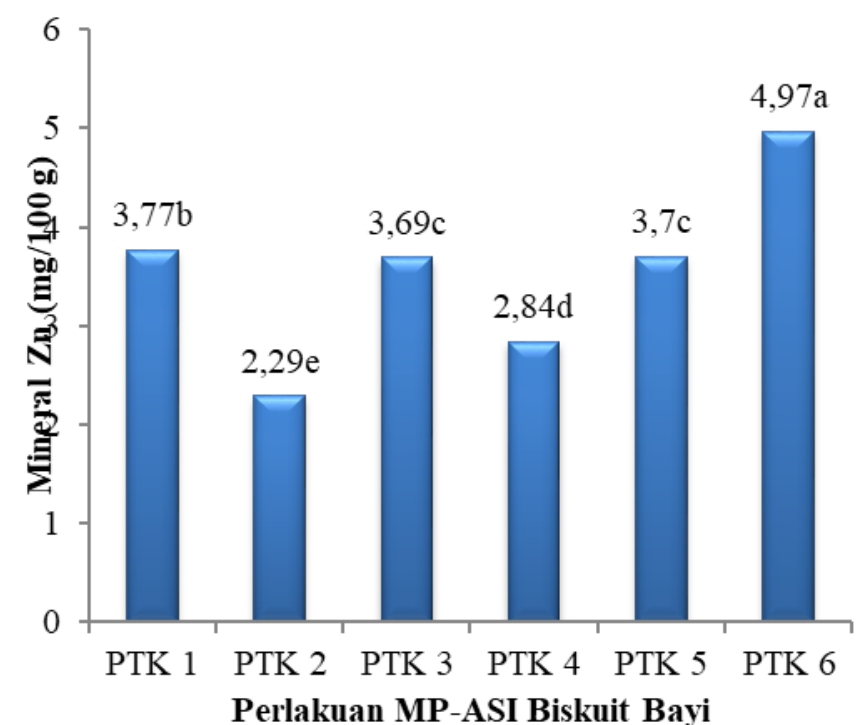

Gambar 3. Hasil analisa mineral Zn (mg/100 g) pada MPASI biskuit bayi

Keterangan: Angka rerata yang diikuti dengan huruf yang sama tidak berbeda nyata pada uji BNT 5\%

*)Perlakuan:

PTK1 = Tepung pisang kepok 100\%

PTK2 = Tepung pisang kepok 90\% : tepung daun kelor $0 \%$ : tepung kacang tunggak $10 \%$

PTK3 = Tepung pisang kepok 80\% : tepung daun kelor 5\% : tepung kacang tunggak $15 \%$

PTK4 = Tepung pisang kepok 70\%: tepung daun kelor 10\%: tepung kacang tunggak $20 \%$

PTK5 = Tepung pisang kepok 60\%: tepung daun kelor 15\%: tepung kacang tunggak $25 \%$

PTK6 = Tepung pisang kepok 50\%: tepung daun kelor 20\%: tepung kacang tunggak $30 \%$ 
Dari Gambar 3 dapat dilihat bahwa perlakuan PTK1 berbeda nyata dengan semua perlakuan, begitu pula dengan perlakuan PTK2 hingga PTK6 berbeda nyata dengan semua perlakuan. Pada Gambar 17 dapat dilihat bahwa pada setiap perlakuan PTK1 menghasilkan kadar Zn yang cukup besar, sedangkan pada perlakuan PTK2 kadar Zn semakin turun setelah dilakukan penambahan tepung kacang tunggak. Pada perlakuan PTK2 keperlakuan PTK3, kadar Zn meningkat, tetapi pada perlakuan PTK4 kadar Zn menurun dan perlakuan PTK5 dan PTK6, kadar Zn semakin meningkat. Pada Gambar 17 dapat dilihat bahwa perlakuan PTK6 menghasilkan kadar Zn yang lebih tinggi. Hal ini menunjukkan bahwa semakin tinggi jumlah penambahan tepung kacang tunggak dan tepung daun kelor maka kandungan Zn akan semakin tinggi. Hal ini dikarenakan kacang tunggak memiliki kandungan Zn yang cukup tinggi yakni sebesar 9,93 $\mathrm{mg} / 100 \mathrm{~g}$ [11].

Menurut SNI 01-7111.2-2005 tentang Syarat mutu MP-ASI biskuit bayi menyebutkan bahwa kandungan Zinc tidak boleh kurang dari 2,5 mg/100 g, hasil analisa menunjukkan bahwa kandungan zinc terendah sebesar $2,84 \mathrm{mg} / 100 \mathrm{~g}$ sehingga semua perlakuan pada pembuatan biskuit MP-ASI dari campuran tepung pisang kepok, tepung kacang tunggak dan tepung kelor memenuhi syarat SNI.

\section{Mineral $\mathrm{Fe}$}

Fe atau zat besi terdapat di dalam tubuh dan diperoleh dari perusakan sel darah merah (hemolisis), besi yang diambil dari penyimpanan di dalam tubuh dan besi yang diserap dari saluran pencernaan. Zat besi berfungsi sebagai metabolisme energi, meningkatkan kemampuan belajar dan meningkatkan sistem kekebalan tubuh[1].

Rerata kadar Fe pada MP-ASI biskuit bayi untuk perlakuan PTK1-PTK6 dalam penelitian ini bervariasi, antara 2,53 - 18,88 mg/ 100 g. Kadar Fe paling rendah adalah pada perlakuan PTK1 $(2,53$ $\mathrm{mg} / 100 \mathrm{~g})$ dan yang tertinggi adalah pada perlakuan PTK6 (18,88 mg/100 g). Hasil analisa ragam (Tabel 2) menunjukkan bahwa perlakuan formulasi pada MP-ASI biskuit bayi berpengaruh nyata $(p<0,05)$ terhadap kadar Fe MP-ASI biskuit bayi yang dihasilkan. Hasil analisa kadar Fe MP-ASI biskuit bayi disajikan pada Gambar 4.

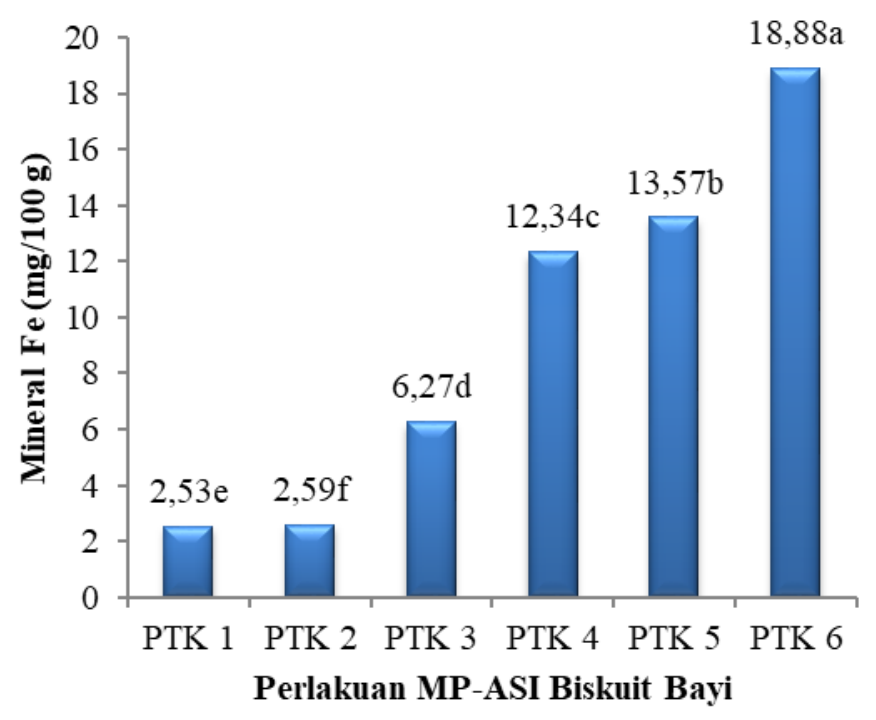

Dari Gambar 16 dapat dilihat bahwa perlakuan PTK1 berbeda nyata dengan semua perlakuan, begitu pula dengan perlakuan PTK2 hingga PTK6 berbeda nyata dengan semua perlakuan. Pada Gambar 16 dapat dilihat bahwa pada setiap perlakuan (PTK1 - PTK6) MP-ASI biskuit bayi dihasilkan kadar Fe yang semakin meningkat. Semakin rendah penambahan tepung pisang kelok dan semakin tinggi penambahan kacang tunggak dan tepung kelor dan maka kadar Fe yang dihasilkan juga semakin meningkat.

Menurut SNI 01-7111.2-2005 tentang Syarat mutu MP-ASI biskuit bayi menyebutkan bahwa kandungan $\mathrm{Fe}$ adalah $>5 \mathrm{mg} / 100$ g. Hasil analisa menunjukkan bahwa perlakuan PTK1 dan PTK2 belum memenuhi syarat karena kandungan $\mathrm{Fe}$ pada kedua perlakuan tersebut di bawah syarat mutu yang ditentukan yaitu sebesar 2,53 dan 2,59 mg/100g.

\section{SIMPULAN DAN SARAN}

Kadar mineral Na dan Zn untuk semua perlakuan MPASI biskuit bayi telah memenuhi jumlah syarat mutu yang ditetapkan (minimal $100 \mathrm{mg} / 100 \mathrm{~g}$ ) dan perlakuan PTK1 (100\% tepung pisang kepok) menghasilkan nilai tertinggi sedangkan untuk mineral Ca menghasilkan kandungan yang tidak memenuhi standar mutu MP-ASI biskuit bayi.

\section{SIMPULAN DAN SARAN}

Kandungan mineral Natrium (Na), Seng (Zn) dan Besi (Fe) pada semua perlakuan telah memenuhi syarat mutu SNI MP-ASI Biskuit bayi, namun kandungan kalsium (Ca) belum memenuhi syarat mutu SNI karena masih dibawah standar. Untuk itu perlu dilakukan penelitian lainnya tentang penggunaan bahan baku lokal untuk memenuhi kebutuhan mineral Ca pada produk MP-ASI biskuit bayi. 


\section{UCAPAN TERIMA KASIH}

Kepada Direktorat Jenderal Pendidikan Tinggi melalui Direkur Penelitian dan Pengabdian Pada Masyarakat atas dana yang diberikan untuk penelitian ini.

\section{DAFTAR RUJUKAN}

\section{Buku}

[1] Cakrawati, D dan Mustika, NH. 2014. Bahan pangan, gizi dan kesehatan. Alfabeta Bandung. Bandung.

[2] Nabrzyski, M., 2002. 'Mineral Component', in Sikorski., Z.E (ed.)., Chemical and Functional Properties of Food Components Second Edition. CRC Press, Boca Raton.

[3] Nanden Kirana. 2006. Finger food kue kecil untuk cemilan. Jakarta: PT Gramedia Pustaka Utama.

[4] Rauf, R., 2015. Kimia Pangan. Penerbit CV. Andi Offset. Yogyakarta.

[5] Winarno, F.G. 2002. Kimia pangan dan gizi. Gramedia Pustaka Utama. Jakarta

\section{Internet}

[6] Morton, J.F. 1987. Banana. www.hort.purdue.edu /newcorp/morton/banana.html. Diakses 30 Desember 2015.

\section{Artikel}

[7] Departemen Kesehatan Republik Indonesia. Pedoman Pemberian Makanan Pendamping ASI. Jakarta: Departemen Kesehatan, 2004.

[8] Kementrian Kesehatan Republik Indonesia. Riset Kesehatan Dasar (Riskesdas). Jakarta: Kementrian Kesehatan, 2010.

[9] SNI 01-7111.2-2005. Makanan pendamping air susu ibu (MPASI) bagian 2: biskuit. Badan Standar Nasional (BSN). Jakarta. 2005

\section{Jurnal}

[10] Aslam, M., F. Anwar, R. Nadeem. 2005. Mineral composition of Moringa oleifera leaves and pods from different regions of Punjab, Pakistan, Asian Journal of Plant Sciences, 4 (4): 417421

[11] Mune, M.A.M., S.R Minka, and I.L Mbome. 2013. Chemical composition and nutritional evaluation of a cowpea protein concentrate, Global Advance Research Journal of Food Science And Technology 2 (3): 35-43 